\title{
Benchmarking PGAA, in-beam NAA, reactor-NAA, and handheld XRF spectrometry for the element analysis of archeological bronzes
}

\author{
Boglárka Maróti ${ }^{1}, Z$ solt Révay ${ }^{2}$, László Szentmiklósi ${ }^{1}$, Krzysztof Kleszcz $^{2,3}$, \\ Dénes Párkányi ${ }^{1}$, Tamás Belgya ${ }^{1}$ \\ ${ }^{1}$ Nuclear Analysis and Radiography Department, Centre for Energy Research, \\ Hungarian Academy of Sciences, Konkoly-Thege Miklós street 29-33, 1121 Budapest, \\ Hungary.E-mail: maroti.boglarka@energia.mta.hu \\ ${ }^{2}$ Forschungsneutronenquelle Heinz Maier-Leibnitz (FRM II), Technische Universität \\ München, Lichtenberg str. 1., 85747 Garching, Germany
}

\begin{abstract}
Novel detection strategies were developed to improve the PGAA methodology in the analysis of bronze and brass objects. Instrumental neutron activation analysis and X-ray fluorescence were also involved in this study for comparison. The approach was tested on a set of IRMM-certified copper alloys. Reference values for the concentrations of four major additive components ( $\mathrm{As}, \mathrm{Zn}, \mathrm{Sn}$, and $\mathrm{Pb}$ ) were compared with the results obtained by the involved methods. The bias observed between the reference $S n$ values and the initial PGAA results was successfully addressed by considering the interference of this line with low intensity copper prompt gamma peaks. In this report results are presented, and the analytical merits are compared.
\end{abstract}

\section{Keywords}

PGAA, In-beam activation analysis, INAA, XRF, IRMM BCR-691, certified reference copper alloys 


\section{Introduction}

The cultural-heritage community is deeply interested in the non-destructive chemical analysis of ancient copper alloys $[1,2]$ to investigate their provenance and manufacturing technology. The widespread analytical techniques, such as energy dispersive X-ray fluorescence (EDXRF), particle induced X-ray emission (PIXE), laser ablation inductively coupled plasma mass spectrometry (LA-ICP-MS), scanning electron microscopy combined with energy-dispersive X-ray spectroscopy (SEM-EDX), laser-induced breakdown spectroscopy (LIBS) all provide analytical information only about a small spot on the surface, unless cross-section samples are taken. Hence, if contamination, surface corrosion or patina are present on the object, the data by these methods may not be representative to the entire object. This can lead to large variation and/or bias of the measured concentrations, and finally to a wrong archaeometric interpretation. However, they proved to be useful to assess, for instance, the required restoration techniques [3, 4]. The representative bulk alloy composition is often obtained by means of destructive chemical analytical methods, such as ICP-MS, ICP-OES or ICP-AAS [2, 3, 5], but invasive chemical analysis is permitted only if non-destructive methods are inapplicable $[1,6]$.

Prompt Gamma Activation Analysis (PGAA) was used for the non-destructive bulk analysis of valuable artefacts already in the late nineties [7], using internal monostandard approach. The $k_{0}$ standardization, the spectroscopic library $[8,9,10]$ and the reliable spectrum-evaluation procedure gave rise to the applications of PGAA for geology, material-science and archaeology samples, including metals [11, 12].

When the matrix contains elements with high neutron-capture cross section, such as copper, the detection of minor and trace components by PGAA is not always successful $[13,14]$. Our aim with the present study was to improve the analytical merit of PGAA in alloy analysis by using tailored irradiation and detection techniques, such as the highresolution PGAA [13], high-flux PGAA [15], PGAA with a $\gamma$-ray attenuator [16] and compare their performances with in-beam activation analysis [15]. Considering the widespread use of reactor-based instrumental neutron activation analysis (INAA) [17] and handheld X-ray fluorescence spectrometry (XRF), these methods served here as references. 
Journal of Radioanalytical and Nuclear Chemistry August 2018, Volume 317, Issue 2, pp 1151-1163 DOI: 10.1007/s10967-018-5990-2

With the single exception of INAA, all other tested approaches are non-destructive, hence applicable to such precious samples.

To avoid any bias due to the potential inhomogeneity or surface-bulk composition difference, the IRMM BCR-691 certified reference materials (CRM) were used for comparison [18] instead of real artefacts.

\section{Materials}

\section{IRMM BCR Certified Reference Materials}

It is a set of five copper alloys (labelled as A-E), intended mainly for calibration [19] or quality control [20-21] of XRF instruments, representing the common ancient bronze and brass types. When using micro beam methods on the BCR-691 CRMs, the recommendations regarding the minimum mass or spot size must be strictly followed [22] due to the micro-scale inhomogeneities, as reported by Constantinides et al [18] and Arana et al [23]. When using PGAA, these inhomogeneities have no effect on the analytical results as the analyzed volume exceeds several $\mathrm{mm}^{3}$.

\section{Quaternary alloy (A)}

This simulated alloy represents the latest ancient alloy-type from this set of CRMs [22]. Quaternary alloy consists of four different metals, in this case: $\mathrm{Cu}, \mathrm{Pb}, \mathrm{Sn}$ and $\mathrm{Zn}$. This is a typical alloy-type of the Roman Age $[22,24]$, mostly made of recycled materials.

\section{$\underline{\operatorname{Brass}(\mathrm{B})}$}

The second latest alloy type from the BCR set is the zinc containing copper alloy, the brass. The beginning of deliberate production of brass is dated around the first Millennium BC [25]. Besides $\mathrm{Cu}$, the matrix component and $\mathrm{Zn}$, the main alloy component, this CRM contains $2 \mathrm{~m} \%$ (mass percent) tin.

\section{Arsenic-copper (C)}


Journal of Radioanalytical and Nuclear Chemistry August 2018, Volume 317, Issue 2, pp 1151-1163 DOI: 10.1007/s10967-018-5990-2

This early type of copper-alloy was produced already from the forth Millennium BC [26]. Arsenic was probably not always an intentional addition, as copper oxide ores often contain a mixture of primary sulphides, in which the arsenic quantity was dependent on the proportion of the arsenic sulphide minerals [26]. Arsenic in certain amounts, similarly to tin, influences positively on the properties of the casting, but due to its volatile and toxic nature, arsenic-copper was not used more extensively later [27].

\section{$\underline{\text { Lead-bronze (D) }}$}

Lead, as an alloying element is known from the Late Bronze Age (Hallstatt B period, 1000$800 \mathrm{BC})$. Its importance increased during the Iron Age (800-100 BC), especially with the appearance of the ternary alloys in the Celtic metalwork culture [28].

\section{$\underline{\text { Tin-bronze }(\mathrm{E})}$}

Tin was intentionally added to copper to make its physical properties and moldability better. The alloy of copper and tin is called bronze. By the appearance of this alloy-type, a new prehistoric period started, namely the Bronze Age. At lower concentrations (1-4 m\%), tin improves the malleability, hardness and tensile strength of the alloy. However, the majority of the Bronze Age bronzes contains tin in about 8-12 m\% [27].

\section{Experimental and data analysis}

\section{PGAA-based detection strategies}

(1) Conventional PGAA measurements were carried out at the PGAA station of the Budapest Neutron Centre (BNC) using a 27-\% HPGe detector with BGO Comptonsuppressor and a cold-neutron beamline with a thermal equivalent neutron flux of $9 \times 10^{7} \mathrm{~cm}^{-2} \mathrm{~s}^{-1}[29]$.

(2) High-flux PGAA measurements (with the flux of $2 \times 10^{8} \mathrm{~cm}^{-2} \mathrm{~s}^{-1}$ ) were performed at the FRM II reactor at the Heinz Meier-Leibnitz Zentrum (MLZ) Garching, Germany [30] with a 60-\% efficient, Compton-suppressed HPGe detector in order 
to see whether the analytical results can be improved just by making the counting statistics better.

In addition to these standard cases, we used the following modifications to the Budapest and Garching PGAA setups:

(3) PGAA with a $\gamma$-ray attenuator between the sample and the detector was used to suppress the high count rate from the low-energy gamma rays of copper. The intensity of the low-energy peaks can be reduced with this filter by a factor of 75-80 or more, relative to the $7915 \mathrm{keV}$ prompt-gamma line of copper, while - by maintaining the same overall count rate limited by the counting electronics - the specific count rates of the high-energy peaks, including those from the minor components, could be enhanced. Similar gamma-ray attenuation method was applied successfully on samples with high boron content [16] and tested on two pieces of certified bronze alloys [14]. In our case, a 10-mm thick lead plate was used, whose gamma-ray attenuation as a function of energy was carefully characterized.

(4) High-resolution PGAA is based on the use of a planar low-energy germanium (LEGe) detector equipped with a BGO Compton-suppressor. It can detect the elements with intense low-energy lines, typically below $500 \mathrm{keV}$ where this detector type has a significantly better resolution than the typically used co-axial semiconductor detectors. Its efficiency falls quickly towards the high energies, thus, the vast amount of analytically unuseful counts in the continuum region (1-5 $\mathrm{MeV}$ ), related to the Compton-plateaus of the high-energy prompt-gamma lines and the unresolvable closely-spaced capture-cascade lines are inherently not registered [13]. Using this configuration, we focused on the more selective identification and evaluation of the most prominent analytical lines, making some so-far unreliable analytical peaks useful.

The spectrum evaluation was performed in all cases using the Hypermet-PC [31] and PeakFit programs [32], whereas the concentration calculation was carried out with the Excel package ProSpeRo [33, 34]. 


\section{In-beam activation analysis}

The idea of in-beam activation analysis, i.e. the combination of a PGAA with offline gamma-counting was introduced in 2008 [35]. Even oversized samples with dimensions exceeding the size of the irradiation capsules of INAA can be analyzed this way. The samples are irradiated in a horizontal channel or in a guided-neutron beamline preferably combined with a PGAA measurement. The in-beam activation is followed by a separate off-line counting step using an HPGe detector in a low-background chamber [15], just like in INAA. The lower flux compared to that of a vertical irradiation channel is at least partly compensated by the use of more massive samples. As the samples might be larger than the beam cross section, the irradiated mass is not known exactly. The element mass ratios from the decay measurement can be scaled to an absolute concentration using an internal standard also determined with PGAA.

The advantage of a cold-neutron beam for in-beam activation analysis is that all nuclides strictly follow the $1 / v$ law and epithermal activation is completely avoided, so calculation is simple. But, if an element with high resonance integral (e.g. As, Ag, Sn, Sb) [36] is to be quantified, the irradiation can take place (even as a byproduct of an imaging experiment) at a horizontal thermal beam port of a reactor, such as the RAD station of BNC [37], where the more energetic neutrons and the larger beam dimensions allow the activation of objects up to $10-15 \mathrm{~cm}$ size with a good representativity, but in exchange, the activation calculations are more complicates.

The irradiation times at cold-neutron PGAA beamline of MLZ were 2-5 minutes with a flux of $3 \times 10^{10} \mathrm{~cm}^{-2} \mathrm{~s}^{-1}$ [30]. Subsequently, three off-line decay measurements were performed on each sample, the first immediately after the irradiation, the second after 3060 minutes of cooling time, and the third one after 2-3 days. The concentration calculation relied on the $k_{0}$ database $[36,38]$ and on the general formulae of INAA simplified to subthermal activation, containing the saturation $(S)$, decay $(D)$ and counting $(C)$ factors to account for the growth of the radionuclide during activation, as well as its decay during cooling and counting times. The formula used for concentration calculation is partly derived from equation (2) of [33] used for calculation of masses in a prompt gamma 
spectrum. Eq. (1) contains the $S D C$ factors as well, as during the decay counting the gamma rays of the radioactive daughter nuclei are measured.

$$
\frac{A}{\varepsilon t}=n \sigma \Phi S D C
$$

where $n$ is the number of target atoms in the analyzed volume and sigma is the thermal neutron capture cross-section, $\Phi$ is the thermal-equivalent neutron flux, $\varepsilon$ is the counting efficiency, $t$ is the measurement time.

\section{$k_{0}$ instrumental neutron activation analysis}

Due to the limited volume of the irradiation capsule used in a vertical channel, destructive sampling was needed for INAA measurements, which would not necessarily be possible for real artefacts. Therefore, these measurements were carried out as a final step of the work. In order to meet the minimum sampling requirement of the IRMM standard (100 mg, or XRF spot size of $5 \mathrm{~mm}$ in diameter) and the study on the certification procedure [18], approximately $100 \mathrm{mg}$ from each copper alloy standard was taken. The sub-samples were cleaned with alcohol, dried, precisely weighed, loaded into polyimide carrier capsules together with the $\mathrm{Au}, \mathrm{Fe}$ and $\mathrm{Zr}$ flux monitors. The samples were irradiated for $180 \mathrm{sec}$ using the fast-rabbit irradiation channel where the neutron flux is $5.3 \times 10^{13} \mathrm{~cm}^{-2} \mathrm{~s}^{-1}$, and is well thermalized $(f \approx 37)$ [17], so the best detection limits were expected from this technique. The irradiated samples were cooled and measured twice in a low-background counting chamber. The first decay measurements took place after seven days. The acquisition times were set to 40 minutes. The second gamma counting took place 66 days after the irradiation, when all short-lived radionuclides had decayed away, reducing the general Compton-background. The acquisition time was four hours for each sample. The counting system consisted of an Ortec 55-\% HPGe detector, an Ortec DSPEC 502 spectrometer operated in zero-dead-time (ZDT) mode, and a low-level counting chamber made of pre-WW2 iron. For the evaluation of the NAA data we applied the $k_{0}$ approach using the Hyperlab 2013 [39] and Kayzero for Windows 3 [40]. The neutron self-shielding was corrected for as described in Ref [41]. 
Journal of Radioanalytical and Nuclear Chemistry August 2018, Volume 317, Issue 2, pp 1151-1163 DOI: 10.1007/s10967-018-5990-2

\section{X-ray fluorescence spectrometry}

The XRF spectrometry measurements were completed using an Innov-X Delta Premium type handheld XRF analyzer. This equipment is designed for the (on-site) analysis of contemporary metal alloys, but it is suitable for the analysis of other materials (e.g. ores, soils) as well where matrix-specific calibration is available. Such device is often used in archaeometry due to its simplicity and low analysis cost.

In our study, its Alloy Plus settings were applied, even though this mode of the instrument does not report the As-content, an indicative constituent of the ancient copper-based alloys. The X-ray spot size was $3 \mathrm{~mm}$ in diameter $\left(\sim 7 \mathrm{~mm}^{2}\right)$, and five measurements were statistically averaged. Each measurement took 30 seconds, and elemental-composition calculation (based on the Fundamental Parameters approach) was done by the built-in software of the device. The other main advantage of the handheld XRF analyzer is that, similarly to PGAA, it does not require any sample preparation either.

\section{Revised interference correction for PGAA}

In a usual bronze PGAA spectrum, only the three most intense tin peaks can be detected: at $1293.5 \mathrm{keV}, 1171.3 \mathrm{keV}$ and $1229.6 \mathrm{keV}$, with relative intensities of $100 \%, 65.6 \%$ and $50.3 \%$, respectively. The minor copper lines close to these tin lines have relative intensities of about $1-4 \%$ (Table 1). Next to the $1229 \mathrm{keV}$ tin line we identified a weak copper peak at $1231.756(61) \mathrm{keV} \mathrm{[10].}$

Table 1: prompt gamma peaks of tin and copper located between 1171 and $1320 \mathrm{keV}$ [10].

\begin{tabular}{cccc} 
Element & Energy [keV] & $\begin{array}{c}\text { Unc. } \\
\text { Energy } \\
{[\mathbf{k e V}]}\end{array}$ & $\boldsymbol{\sigma}_{\gamma}$ \\
\hline $\mathrm{Sn}$ & 1171.282 & 0.059 & $0.0879(13)$ \\
$\mathrm{Sn}$ & 1229.644 & 0.059 & $0.0674(13)$ \\
$\mathrm{Cu}$ & 1231.756 & 0.061 & $0.0102(8)$
\end{tabular}


Journal of Radioanalytical and Nuclear Chemistry August 2018, Volume 317, Issue 2, pp 1151-1163 DOI: 10.1007/s10967-018-5990-2

$\begin{array}{lcll}\mathrm{Cu} & 1241.715 & 0.079 & 0.0346(12) \\ \mathrm{Sn} & 1293.53 & 0.059 & 0.1340(21) \\ \mathrm{Cu} & 1320.037 & 0.042 & 0.0219(8)\end{array}$

The partial gamma-ray production cross section of $1229.6-\mathrm{keV}$ tin line has a cross section of $0.0673(13) \mathrm{b}$, while the $1231.8 \mathrm{-keV}$ copper line has $0.0102(8) \mathrm{b}$. Considering that the bronze contains 20-60 times more $\mathrm{Cu}$ atoms than $\mathrm{Sn}$ (see Table 2), the count rates of the overlapping peak pairs become comparable. At lower tin concentrations, the count rate of the copper peak can be 6-20 times more than that of the close-lying tin peak.

Table 2: $\mathrm{Cu}-\mathrm{Sn}$ atomic ratios calculated into mass percentage unit and the produced analytical signal.

\begin{tabular}{|c|c|c|c|}
\hline $\begin{array}{c}\mathrm{Sn}: \mathrm{Cu} \\
\text { atomic } \\
\text { ratio }\end{array}$ & $\underset{\operatorname{mass} \%}{\operatorname{Sn}}$ & $\underset{\text { mass }}{\mathrm{Cu}}$ & $\begin{array}{c}\text { Analytical } \\
\text { signal (ratio) } \\
\mathrm{Cu} / \mathrm{Sn}\end{array}$ \\
\hline $1: 1$ & 65 & 35 & 0.15 \\
\hline $1: 5$ & 27 & 73 & 0.76 \\
\hline 1:10 & 16 & 84 & 1.5 \\
\hline $1: 15$ & 11 & 89 & 2.3 \\
\hline $1: 20$ & 9 & 91 & 3 \\
\hline $1: 40$ & 4.5 & 95.5 & 6.1 \\
\hline $1: 50$ & 3.6 & 96.4 & 7.6 \\
\hline 1:100 & 1.8 & 98.2 & 15.2 \\
\hline
\end{tabular}

Table 3: reference values for tin in the copper alloys compared to the conventional PGAA results (without the advanced correction detailed in the text). Note that in case of two mass percent tin content the bias is more than $50 \%$.

\begin{tabular}{lrrrrr} 
Alloy & $\begin{array}{c}\text { Tin mass percent } \\
\text { Reference } \\
\text { value }\end{array}$ & $\begin{array}{c}\text { STD } \\
\text { Ref. }\end{array}$ & PGAA & $\begin{array}{c}\text { PGAA } \\
\text { STD } \\
(\mathbf{k = 2})\end{array}$ & $\begin{array}{c}\text { PGAA / } \\
\text { Reference } \\
\text { value }\end{array}$ \\
\hline Arsenic-copper (BCR-C) & 0.202 & 0.01 & ND & & \\
Brass (BCR-B) & 2.06 & 0.035 & 3.4 & 0.4 & 1.65 \\
Tin-bronze (BCR-E) & 7 & 0.3 & 9.8 & 0.8 & 1.40 \\
Quaternary bronze (BCR-A) & 7.16 & 0.105 & 7.5 & 0.9 & 1.05 \\
Lead-bronze (BCR-D) & 10.1 & 0.4 & 11.5 & 0.8 & 1.14
\end{tabular}


Journal of Radioanalytical and Nuclear Chemistry August 2018, Volume 317, Issue 2, pp 1151-1163 DOI: 10.1007/s10967-018-5990-2

Table 3 lists the observed bias between the reference values and the concentrations obtained with the uncorrected standard PGAA methodology. It was realized that the magnitude of the bias is in anti-correlation with the Sn content, i.e. the cause of this bias is not the incorrect cross section value, but the inappropriate interference correction. The use of the standard interference correction library that contains prompt gamma lines down to $1 \%$ relative intensity $[10,33]$, is proven to be insufficient in this scenario. An extended version, containing additional two hundred $\mathrm{Cu}$ peaks with lower intensities, was created and applied to overcome the problem.

The newly introduced interference correction practice was tested on a tin-bronze European Reference Material (ERM), ERM ${ }^{\circledR}$-EB374, too. It contains $7.6 \mathrm{~m} \%$ tin with negligible amounts of $\mathrm{Ag}, \mathrm{Fe}, \mathrm{Mn}, \mathrm{Ni}, \mathrm{Pb}, \mathrm{Zn}$, at far below 50 ppm quantities. Before the correction, $9.6 \pm 0.3 \mathrm{~m} \%$ tin content was determined, while after the proper interference correction, the tin content became $7.9 \pm 0.3 \mathrm{~m} \%$. The $\mathrm{Sn} / \mathrm{Cu}$ ratios are $0.107 \pm 0.003,0.0824 \pm 0.0014$ and $0.0859 \pm 0.0026$ for the uncorrected result, the reference values and for the adequately corrected PGAA result, respectively.

For the accurate quantification of low-intensity copper lines, high-purity copper sheets with the thicknesses of $7 \mu \mathrm{m}$ and $1 \mathrm{~mm}$ were analyzed (99.9\% purity $\mathrm{Cu} 131710$, ADVENT R. M. Ltd.). In order to convert the relative intensities of these low-intensity gamma lines to partial gamma-ray production cross sections $\left(\sigma_{\psi}\right)$, copper (II) chloride dihydrate was measured for standardization. The partial gamma-ray production cross sections were calculated according to equation 8 in Ref [9]. 


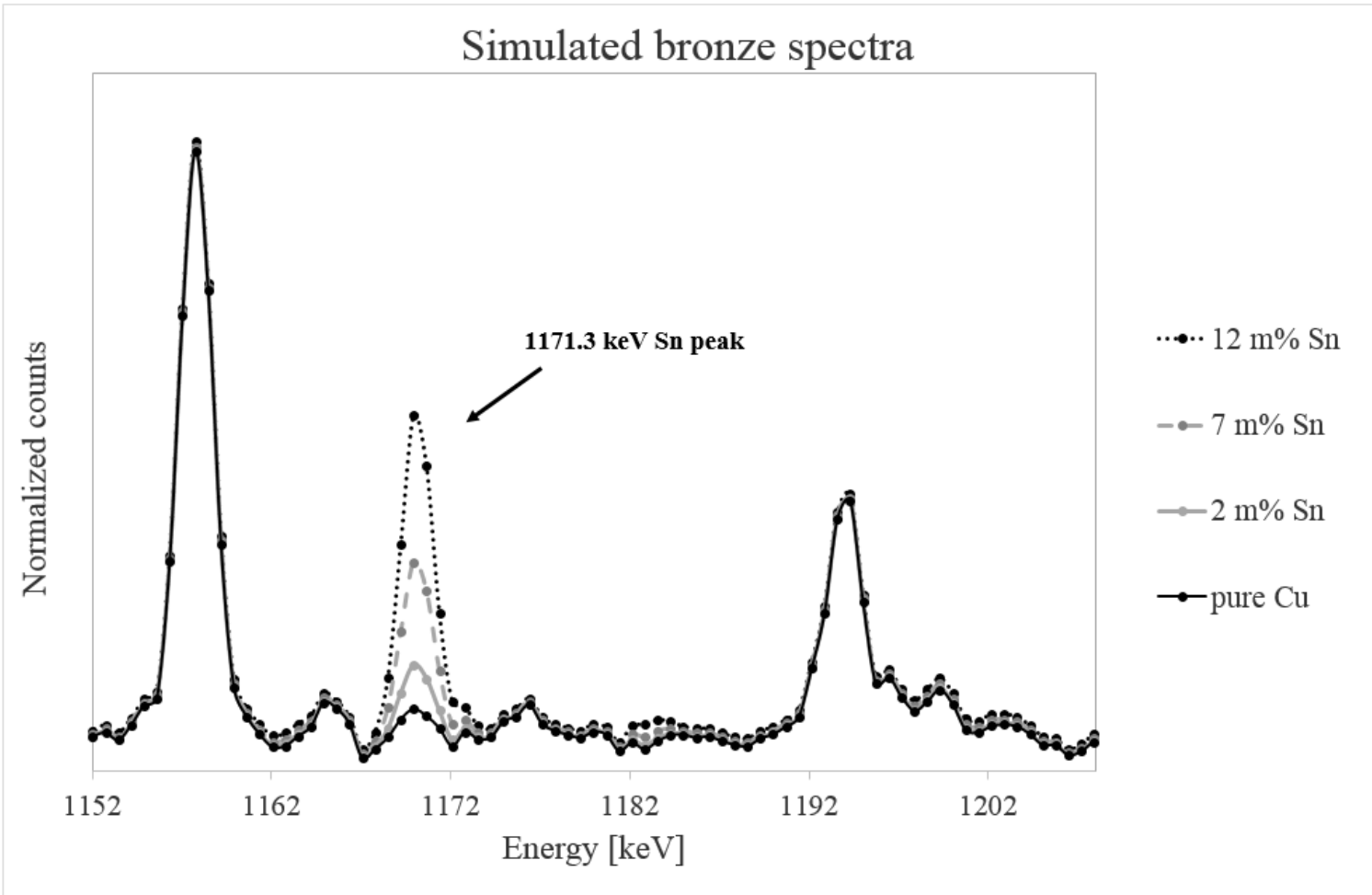

Figure 1: Calculated bronze PGAA spectra with different tin mass fractions. The peak areas are normalized to the copper matrix peaks.

At $1171.345(54)$ and $1293.868(67) \mathrm{keV}$, low-intensity prompt peaks of $\mathrm{Cu}$ were confidently identified (see Fig. 1). The elemental spectra of $\mathrm{Cu}$ and $\mathrm{Sn}$ with appropriate weighting factors representing different mass fractions of $\mathrm{Sn}$, were superimposed to illustrate the overlap at $1171.3 \mathrm{keV}$. In case of a $2 \mathrm{~m} \%$ Sn content, the weak copper peak contributes to the area of $1171.3-\mathrm{keV}$ peak by $50 \%$, being the reason of the observed positive bias.

The calculated partial cross section values for 1171 - and $1293-\mathrm{keV} \mathrm{Cu}$ lines are $0.00126(13)$ and 0.00165(13) barn, respectively. These interferences were correctly taken into account during the concentration calculation stage. The summary of results with the revised tin concentrations is detailed later in the Table 4.

\section{Results}



1151-1163 DOI: 10.1007/s10967-018-5990-2

Table 4: results of the quaternary alloy, brass, arsenic copper, lead-bronze and tinbronze samples (BCR-691 A-E) using different PGAA settings and a handheld XRF device in $\mathrm{m} \%$ unit. Reference and informative values together with NAA and PIXE results from previous studies are also involved [18, 22, 23].

\section{SEE AT THE END OF THE DOCUMENT}

\section{Quaternary alloy}

The four major constituents of the Quaternary alloy, $\mathrm{Cu}, \mathrm{Pb}, \mathrm{Sn}$ and $\mathrm{Zn}$ are all above $1 \mathrm{~m} \%$ quantity, they could be quantified by all the methods involved in this study, except lead. $\mathrm{Pb}$ was not detected by INAA and in-beam NAA, since lead has no detectable radioactive daughter nuclide. $\mathrm{Pb}$ has a single prompt-gamma line at $7368 \mathrm{keV}$ with low neutron capture cross section. High-resolution PGAA has orders of magnitude lower efficiency above $2000 \mathrm{keV}$, so this lead peak could not be detected using this setup. Except for attenuated PGAA and handheld XRF, arsenic content was analyzed with all methods within uncertainty margin. Note, that attenuated PGAA is not sensitive for the low-energy gammas on purpose. The poor sensitivity for arsenic is not the feature of the XRF method, but the weakness of the handheld device's embedded evaluation software. As, $\mathrm{Ni}$ and $\mathrm{Sb}$ can provide valuable information about the used ores during the production of the real ancient alloys. As the $\mathrm{Ni}$ and $\mathrm{Sb}$ were added to the mixture during the production of the simulated alloys, it can be concluded, that high-resolution PGAA, in-beam NAA, INAA and XRF methods are essential in the analysis of Sb. Nickel was detected with conventional and attenuated PGAA and with XRF. Silver content was observed using high-resolution PGAA and INAA. As no information on silver addition in the CRM is available, this element is considered as a component in one of the metal powders.

Both polished (front) side and flattest part of the rear side of the CRMs were measured with handheld XRF. Table 4 contains the XRF results of the measurements carried out on the polished side. The front and the rear side has a $\mathrm{Pb}$ content of $8.1 \pm 0.6 \mathrm{~m} \%$ and $6.4 \pm$ $0.5 \mathrm{~m} \%$, respectively, i.e. they showed more than $20 \%$ difference in lead content. 


\section{Brass}

Tin was successfully determined with conventional and attenuated PGAA, using the proper interference corrections. Due to the detector efficiency, Sn could not be reported by highresolution PGAA. Using in-beam NAA and off-line counting measurements, tin could be determined via its $\mathrm{Sn}-123 \mathrm{~m}$ radionuclide. The determined concentrations agreed within one sigma.

$\mathrm{Pb}$ contents on the polished and the rear side agreed within uncertainty in case of the handheld XRF results. However, the observed $\mathrm{Pb}$ concentrations here were $25 \%$ above the reference value. This can be the consequence of the low $\mathrm{Pb}$ content $(0.39 \%)$, and the arsenic content $(0.099 \%)$ together.

\section{Arsenic-copper}

This type of copper alloy could be analyzed successfully with all our techniques (except for the As content by XRF). The only hindering fact was that in addition to arsenic and copper, the remaining low amount of $\mathrm{Zn}, \mathrm{Sn}, \mathrm{Pb}$ content could be only detected by XRF. Zn was reported by NAA, which requires destructive sampling.

As for XRF, the $50 \%$ bias from the reference value, and the $20 \%$ difference between the lead content of the two sides can partly be attributed to the high arsenic content (as an interfering element).

\section{Lead-bronze and tin-bronze}

If our specimen is lead-bronze or lead-containing tin bronze, besides conventional PGAA, PGAA with $\gamma$-ray attenuator and XRF can be methods of choice. Both lead and tin emit prompt gammas above $1 \mathrm{MeV}$ as well as nickel, which, in real bronzes could be an impurity of the raw material [27].

While in case of a tin bronze (E) sample, the lead difference between the two sides was not observed in the XRF results, lead-bronze (D) showed the highest (30\%) deviation in $\mathrm{Pb}$ concentrations (polished side: $10.9 \pm 0.6 \mathrm{~m} \%$, rear side: $7.5 \pm 0.4 \mathrm{~m} \%$ ). 

1151-1163 DOI: 10.1007/s10967-018-5990-2

In case of the $\mathrm{Zn}$ content of both the lead- and the tin-bronze, the XRF device erroneously calculates the detection limit for $600 \mathrm{ppm}$, yet, the $\mathrm{Zn}$ content of the alloys is higher than this value in both cases.

\section{Discussion}

When ancient metal artefacts from museum collections are analyzed, the turnaround time has also to be taken into consideration. Regarding the rapidity of the measurement, XRF cannot be challenged. Table 5 summarizes the characteristics and the time requirements of the applied methods. In case of conventional, attenuated and high-resolution PGAA, the samples are available 1-2 days after the irradiation. During in-beam activation analysis, a medium half-life nuclide, $\mathrm{Sb}-122$ can be formed ( $\mathrm{T}_{1 / 2}=2.7$ days). Depending on the quantity of the $\mathrm{Sb}$ in the examined object and the irradiated mass, the artefact should be stored for more than one week in the laboratory in order meet the legal clearance level.

Table 5: performance indicators of the different neutron-based analytical methods.

\begin{tabular}{|c|c|c|c|}
\hline Method & $\begin{array}{c}\text { Collimator } \\
\text { size }\end{array}$ & $\begin{array}{l}\text { Actual } \\
\text { irradiated } \\
\text { mass }(\mathbf{g})\end{array}$ & Turnaround time of the whole analysis procedure \\
\hline $\begin{array}{c}\text { Conventional } \\
\text { PGAA }\end{array}$ & $10-24 \mathrm{~mm}^{2}$ & $0.2-0.5 \mathrm{~g}$ & $\begin{array}{l}\mathbf{2 - 5} \text { hours } \\
\text { (1-3 hours of measurement, } 1.5 \text { hour of spectrum evaluation) }\end{array}$ \\
\hline $\begin{array}{c}\text { Attenuated } \\
\text { PGAA }\end{array}$ & $24-44 \mathrm{~mm}^{2}$ & $0.5-1 \mathrm{~g}$ & $\begin{array}{l}\mathbf{2 - 3} \text { hours } \\
\text { (1-2 hours of measurement, } 0.5-1 \text { hour of spectrum evaluation) }\end{array}$ \\
\hline $\begin{array}{l}\text { High- } \\
\text { resolution } \\
\text { PGAA }\end{array}$ & $24-44 \mathrm{~mm}^{2}$ & $0.5-1 \mathrm{~g}$ & $\begin{array}{c}\text { 1-2 hours } \\
(0.5-1.5 \text { hours of measurement, } 0.5 \text { hour of spectrum } \\
\text { evaluation })\end{array}$ \\
\hline $\begin{array}{l}\text { In-beam } \\
\text { activation } \\
\text { analysis }\end{array}$ & $150 \mathrm{~mm}^{2}$ & $1-3 \mathrm{~g}$ & $\begin{array}{c}\text { 3-4 days } \\
\text { (5 minutes of irradiation, total of } 4 \text { hours gamma spectrometry } \\
\text { measurements, } 3-4 \text { days cooling time, } 0.5 \text { hour of spectrum } \\
\text { evaluation per sample) }\end{array}$ \\
\hline INAA & N/A & $100 \mathrm{mg}$ & $\begin{array}{c}\text { 15-70 days } \\
\begin{array}{c}(180 \mathrm{sec} \text { irradiation, } 7+60 \text { days of cooling time, } 1-2 \text { hours of } \\
\text { spectrum evaluation in batch mode })\end{array}\end{array}$ \\
\hline
\end{tabular}


Journal of Radioanalytical and Nuclear Chemistry August 2018, Volume 317, Issue 2, pp 1151-1163 DOI: 10.1007/s10967-018-5990-2

The conventional PGAA protocol reported $\mathrm{As}, \mathrm{Zn}, \mathrm{Cu}, \mathrm{Pb}$ concentrations in agreement within the uncertainty margin to the certified value, while Sn was initially overestimated (with 5-65\%). After revising the interference correction procedure, the results became compatible with the reference values.

From the additional elements $(\mathrm{Sb}, \mathrm{Ni}, \mathrm{Mn}, \mathrm{Fe})$ used during the production of the simulated copper-alloys [22], Ni was detected in all cases, while Mn in three samples and Fe only in the brass. Sb was not detected, being below the detection limit of the technique in this matrix.

PGAA with gamma-ray attenuator provided results with better statistics for elements having high-energy lines, such as $\mathrm{Pb}, \mathrm{Mn}$ and $\mathrm{Ni}$, thanks to the higher number of counts acquired in their respective peaks. For BCR-691 A and E, Sn was found to be an outlier when using this mode for the same reason as discussed above. After using the proper interference correction, the results became in line with the reference values. As a side effect of the gamma attenuator between the sample chamber and the detector, elements with strong low-energy gamma lines, such as Sb and As could not be detected.

In high-resolution PGAA mode, the LEGe detector has proven to be a useful addition to the standard PGAA system. The emerging high-intensity, often overlapping gamma lines in the low-energy range could be successfully resolved by the LEGe detector, in contrast to the conventionally used co-axial HPGe, whereas the high-energy part of the spectrum is suppressed due to the diminishing efficiency. Therefore, in addition to standard PGAA, the Sb content in the BCR-691 A, C, D and E samples became quantifyable using the lowenergy gamma lines (Sample B does not contain $\mathrm{Sb}$ ). In resolving multiplets, the peakfitting patterns significantly differed from that of the PGAA, hence, targeted nuclear-data measurements were carried out to arrive at correct concentrations.

The high-flux PGAA reduced acquisition time but did not seem to be beneficial in case of copper alloys. The high count rate drives the electronics beyond their optimum performance, so the peak shapes are distorted and due to the increased chance of random coincidences the baseline in the spectrum is increased. For that reason, the results are not reliable and less precise than with the standard PGAA methodology. 
Journal of Radioanalytical and Nuclear Chemistry August 2018, Volume 317, Issue 2, pp 1151-1163 DOI: 10.1007/s10967-018-5990-2

To achieve the best detection limit for minor and trace components when using in beam NAA, it is required to wait until the radioactive nuclides of the matrix decay away. This is possible, if the radionuclides of the major constituents have shorter half-lives than the other components of interest. In case of in-beam activation analysis, unlike $k_{0}-\mathrm{NAA}$, we need to detect the signal of the matrix components as well, because the other components (As, Sn, $\mathrm{Sb}, \mathrm{Zn}, \mathrm{Mn}$ ) can be given only relative to a main constituent, and scaled to absolute masses via the $\mathrm{Cu}$ data from the standard PGAA.

The decay gamma-ray peaks that were found to be the most reliable for quantification are listed in Table 6.

Table 6: peaks found to be useful in decay gamma-spectrometry following cold neutron irradiation.

\begin{tabular}{cccc} 
Energy $(\mathbf{k e V})$ & Half-life & Decay mode & Radioactive nuclide \\
\hline 511 & $12.7 \mathrm{~h}$ & $\beta+$ & $\mathrm{Cu}-64$ \\
1345 & $12.7 \mathrm{~h}$ & $\beta-$ & $\mathrm{Cu}-64$ \\
1039 & $307.2 \mathrm{~s}$ & $\beta-$ & $\mathrm{Cu}-66$ \\
$847,1811,2113$ & $2.58 \mathrm{~h}$ & $\beta-$ & $\mathrm{Mn}-56$ \\
439 & $13.7 \mathrm{~h}$ & $\mathrm{IT}$ & $\mathrm{Zn}-69 \mathrm{~m}$ \\
$559,657,1216$ & $1.09 \mathrm{~d}$ & $\beta-$ & $\mathrm{As}-76$ \\
160 & $2404 \mathrm{~s}$ & $\beta-$ & $\mathrm{Sn}-123 \mathrm{~m}$ \\
564 & $2.72 \mathrm{~d}$ & $\beta-$ & $\mathrm{Sb}-122$
\end{tabular}

Besides XRF, Instrumental neutron activation analysis could detect the most elements (with the exception of $\mathrm{Pb}, \mathrm{Fe}$ and $\mathrm{Ni}$ ), and its detection limits were the most advantageous. Mn was also not detected, as after the irradiation, the radioactivity was too high. Due to radiation protection reasons, the samples were stored in the depot of the fast rabbit system. The first measurement was carried out after 8-10 half-lives of $\mathrm{Cu}-64$, and during this time the Mn-56 completely decayed away, as its half-life is 2.58 hours.

The built-in software of the Olympus Delta Premium XRF analyzer does not report the arsenic concentration. To overcome this limitation, bAxil XRF spectrum fitting software [42] was used. The main difficulty is the simultaneous determination of arsenic and lead in the same sample, because the $10.5 \mathrm{keV}$ arsenic $\mathrm{K} \alpha$ line strongly interferes with $\mathrm{Pb} \mathrm{L} \alpha$. Using bAxil software, lead and/or arsenic $\mathrm{K} \alpha$ was detected in all spectra. Arsenic $\mathrm{K} \beta$ was 
clearly visible in the arsenic copper alloy (BCR-C) and could be fitted in the spectra of the remaining alloys, too. The relative uncertainly of the arsenic $\mathrm{K} \beta$ peak is $11 \%$ in case of BCR-E. For BCR-A-B-D the K $\beta$ peak area uncertainty is $30-35 \%$. Lead M $\alpha$ line could only be detected in case of BCR-A and D alloys, where the lead content is 7.9 and $9.2 \mathrm{~m} \%$, respectively. The handheld XRF measurements revealed significant compositional differences between the polished and the rear sides of the alloy discs, especially in the cases of $\mathrm{Mn}, \mathrm{Fe}$ and $\mathrm{Pb}$ content. This effect was especially characteristic to the high-lead containing samples (A - quaternary alloy, D - lead bronze). In case of sample $\mathrm{C}$, the signal of $\mathrm{As}$ is erroneously interpreted as $\mathrm{Pb}$ by the analysis software of Innov-X, thus overestimating the $\mathrm{Pb}$ content to a large extent. The proper matrix calibration for arsenic and lead containing copper alloys is under way.

\section{Detection limits}

In case of NAA measurements the Kayzero for Windows 3 [40] software was used for the calculation of detection limit (DL). This program applies the detection limit as defined by Currie [43]. The DL values are calculated for all gamma-peaks present in the spectrum. A possible way to improve the detection limit of the elements of interest is to wait until the radioactive nuclide of the matrix component decays. If the matrix component has comparable or longer half-life than the other constituents, the searched peaks might be covered by the Compton plateau of the higher-energy, intense gamma peaks of the main component, thus worsening the detectability of the elements of interest.

While calculating the DL for the PGAA measurements, the peak-search algorithm settings of the applied spectrum fitting software [31,32] needs to be taken into account [44] in addition to the Currie criterion [43]. Furthermore, the position of the peak in the prompt gamma spectrum (low-energy or high-energy range) has important influence on the minimum detectable area. The low-background regions with completely interference-free peaks are preferred. However, in the present study the detection limits might be worse because the spectra are complicated (type 2) [44]. The detection limits for conventional PGAA, attenuated PGAA and high-resolution PGAA are calculated using Equation 23 of the Handbook of Prompt Gamma Activation Analysis [44], from selected intense, 
Journal of Radioanalytical and Nuclear Chemistry August 2018, Volume 317, Issue 2, pp 1151-1163 DOI: 10.1007/s10967-018-5990-2

preferably interference-free prompt gamma peaks. In our case, $\mathrm{t}_{\max }$ in Equation 23 (which was referred to as the longest practicable measurement time and was defined in $100000 \mathrm{~s}$ in Ref [44]) was replaced by the live-time of the individual measurements i.e. reasonable acquisition times (3000-9000 sec).

Using in-beam activation analysis, the detection limit of a certain element is strongly dependent on the neutron flux, the irradiation time, the cooling time before measurement and the half-life of the formed radionuclides present in the sample. Note, that the detection limits can be slightly varied, if the measurement conditions change. The calculated detection limits are valid for 5 minutes of irradiation.

The detection limits of the handheld XRF were calculated by the built-in software of the device.

The detection limits of all different techniques used in this study are listed in Table 7, for a general overview.

Table 7: detection limits (mass percents or $\mu \mathrm{g} / \mathrm{g}$ noted as $\mathrm{ppm}$ ) of possible minor and trace elements in different copper-based alloys.

$\begin{array}{lcccccc}\text { Element } & \text { NAA } & \begin{array}{l}\text { In-beam } \\ \text { activation } \\ \text { analysis }\end{array} & \begin{array}{l}\text { Conventional } \\ \text { PGAA }\end{array} & \begin{array}{l}\text { Attenuated } \\ \text { PGAA }\end{array} & \begin{array}{l}\text { High- } \\ \text { resolution } \\ \text { PGAA }\end{array} & \text { handheld XRF } \\ \mathrm{As} & 25-50 \mathrm{ppm} & 10-60 \mathrm{ppm} & 0.06-0.6 \% & 1.1-10 \% & 0.05-0.10 \% & \text { N/A } \\ \mathrm{Pb} & \mathrm{N} / \mathrm{A} & \mathrm{N} / \mathrm{A} & 3.0-6.0 \% & 1.7-3.5 \% & \mathrm{~N} / \mathrm{A} & 200-800 \mathrm{ppm} \\ \mathrm{Zn} & 90-150 \mathrm{ppm} & 0.3-1.2 \mathrm{~m} \% & 1.0-1.5 \% & 1.6 \% & 0.6 \% & 400-2000 \mathrm{ppm} \\ \mathrm{Sn} & 0.45-0.8 \% & 0.23-0.3 \mathrm{~m} \% & 1.5-2.0 \% & 0.5-1.0 \% & 4.0 \% & 150-700 \mathrm{ppm} \\ \mathrm{Sb} & 3-6 \mathrm{ppm} & 5-20 \mathrm{ppm} & 0.8-1.0 \% & \text { N/A } & 0.02-0.1 \% & 200-500 \mathrm{ppm} \\ \mathrm{Ni} & \mathrm{N} / \mathrm{A} & \text { N/A } & 20-400 \mathrm{ppm} & 20-300 \mathrm{ppm} & 0.2-0.7 \% & 200 \mathrm{ppm} \\ \mathrm{Mn} & \text { N/A } & 20-40 \mathrm{ppm} & 0.3-0.5 \% & 0.1-0.3 \% & 0.1-0.3 \% & 50-100 \mathrm{ppm} \\ \mathrm{Fe} & \text { N/A } & \text { N/A } & 0.4-0.6 \% & 0.4-0.6 \% & 0.4-0.6 \% & 300 \mathrm{ppm} \\ \mathrm{Ag} & 15-50 \mathrm{ppm} & \text { N/A } & 0.02-0.05 \% & \text { N/A } & 50-100 \mathrm{ppm} & 200-300 \mathrm{ppm}\end{array}$

N/A indicates if an element cannot be detected due to methodological or nuclear physical reasons.

It is valid for all the neutron-based methods, that the decisive factor is the element of interest relative to the copper amount.

General assessment and recommended workflow 
Journal of Radioanalytical and Nuclear Chemistry August 2018, Volume 317, Issue 2, pp 1151-1163 DOI: 10.1007/s10967-018-5990-2

Different PGAA setups were tested in the analysis of bronze standards containing various amounts of $\mathrm{As}, \mathrm{Pb}, \mathrm{Sn}, \mathrm{Zn}$. Discrepancy was observed between the certified $\mathrm{Sn}$ values and the calculated concentrations in the case of PGAA-based methods. The copper interferences, causing the deviation, were successfully taken into account.

Thanks to different probing volumes of the neutron and X-ray based techniques, inhomogeneity problems, bias in the lead content between front and rear sides can be revealed even for a certified reference material. Lead inhomogeneity is an existing phenomenon in real bronzes as well. It is caused by the insolubility of lead in copper matrix [27]. Element misidentification of the handheld XRF was also recognized, which must be taken care of during its routine applications.

The high-flux mode of PGAA could not yet be utilized routinely for bronze analysis due to instrumental problems, although it becomes practical when only a small amount of sample is available.

PGAA with lead gamma-ray attenuator shortened the required acquisition time and improved the precision of some poorly detectable elements, such as $\mathrm{Sn}, \mathrm{Pb}$ and $\mathrm{Ni}$, which have strong prompt gamma lines above $1 \mathrm{MeV}$. On the other hand, important peaks of $\mathrm{Sb}$ and As in the low-energy part of the spectrum are lost.

Additional $\mathrm{Sb}$ content could be determined using high-resolution PGAA, in-beam activation analysis, NAA and XRF method.

The Ag content detected by NAA and high-resolution PGAA is probably the impurity of one of the used element powders.

The best combination of different PGAA setups to determine the most alloy components is gamma-attenuated PGAA - if the sample is not irregular and its thickness is limited to 2-3 mm - together with high-resolution PGAA or in-beam activation analysis. Lead and nickel can be determined using their high-energy gammas. Elements - undetectable using gamma attenuator - with low-energy gamma rays, all have short-lived radioactive nuclides, and can be analyzed with the help of in-beam activation analysis followed by off-line counting measurements. Furthermore, in-beam activation analysis offers more reliable 

1151-1163 DOI: 10.1007/s10967-018-5990-2

peak identification and less spectral interference. One of the drawbacks of this method is that $\mathrm{Pb}$ cannot be analyzed, and due to the medium half-life radionuclides possibly forming, the sample should be kept in the laboratory for longer time.

The combination of these techniques improves the analytical merits of PGAA in bronze analysis, still in a non-destructive way. Figure 2 depicts a recommended measurement workflow. The completely non-destructive methods can be found within the gray frame.

Figure 2: Proposed measurements for the non-destructive bulk characterization of archaeological copper-alloys.

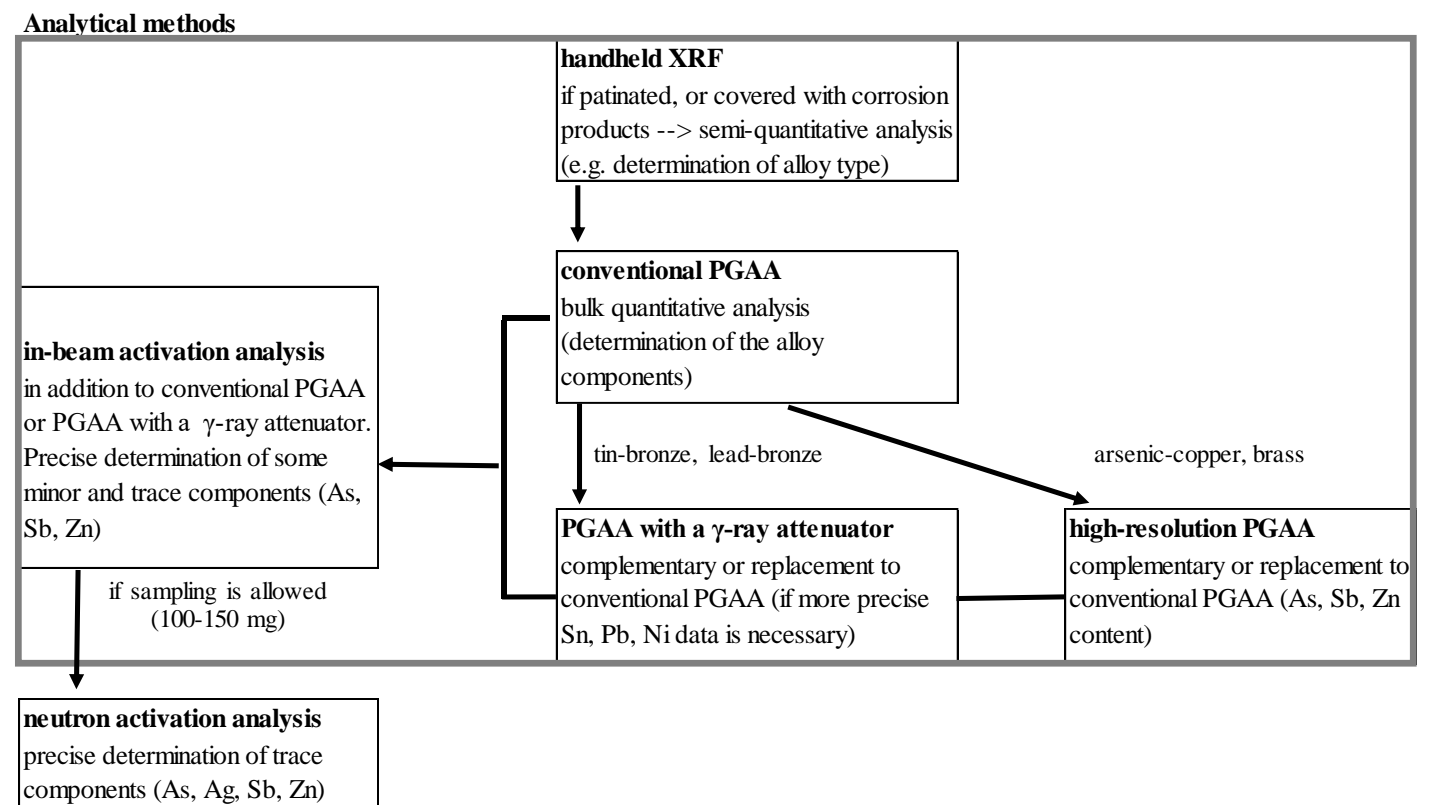

\section{Conclusions}

We managed to develop specific irradiation and detection techniques capable of adding elements to the suite detected by the conventional PGAA measurement. With the introduction of advanced interference correction and considering even the low-intensity copper prompt gamma peaks, the previously overestimated tin concentrations became reliable even in case of low Sn amounts. Depending on the elements of interest, a combination of high-resolution PGAA (sensitive for As, Zn, Sb, Fe, Ag) and attenuated 
Journal of Radioanalytical and Nuclear Chemistry August 2018, Volume 317, Issue 2, pp 1151-1163 DOI: 10.1007/s10967-018-5990-2

PGAA (sensitive for $\mathrm{Pb}, \mathrm{Sn}, \mathrm{Ni}, \mathrm{Mn}, \mathrm{Fe}$ ) is recommended for the measurement of alloying elements and some impurities in copper-alloys. If the samples are of moderate size, conventional PGAA combined with off-line counting (e.g. in-beam activation analysis) is an optimum choice of methodology.

A proposed measurement protocol is appropriate for the analysis of ancient copper and copper-based objects that are not available for destructive sampling, or covered with altered surface layer, such as corrosion or patina.

\section{Acknowledgements}

The authors gratefully acknowledge the financial support provided by FRM II to perform the PGAA measurements at the Heinz Maier-Leibnitz Zentrum (MLZ), Garching, Germany. B. M. thanks the Hungarian Academy of Sciences for the young scientist grant supporting her Ph.D. work. L. Sz. gratefully acknowledges the financial support of the Bolyai János Research Fellowship of the Hungarian Academy of Sciences. This work was part of the project No. 124068 that has been implemented with the support provided from the National Research, Development and Innovation Fund of Hungary, financed under the K_17 funding scheme.

\section{References}

1. Kiss V, Fischl KP, Horváth E, Káli Gy, Kasztovszky Zs, Kis Z, Maróti B, Szabó G (2015) Non-destructive analyses of bronze artefacts from Bronze Age Hungary using neutron-based methods. J Anal At Spectrom. 30:685-693

2. Sessa C, Bagán H, Romero M T, García J F (2017) Effects of variability sources on analysis of the composition of large ancient metal objects. Microchem J. 134:309-316

3. Giumlia-Mair A (2005) On surface analysis and archaeometallurgy. Nucl Instrum Meth B. $239: 35-43$ 
Journal of Radioanalytical and Nuclear Chemistry August 2018, Volume 317, Issue 2, pp 1151-1163 DOI: 10.1007/s10967-018-5990-2

4. Di Turo F, De Vito C, Coletti F, Mazzei F, Antiochia R, Favero G (2017) A multianalytical approach for the validation of a jellified electrolyte: Application to the study of ancient bronze patina Michrochem J. 134:154-163

5. Lutz J, Pernicka E (1996) energy dispersive X-ray fluorescence analysis of ancient copper alloys: empirical values for precision and accuracy. Archaeometry 38:313-323 . doi: 10.1111/j.1475-4754.1996.tb00779.x

6. Mödlinger M, Kasztovszky Zs, Kis Z, Maróti B, Kovács I, Szőkafalvi-Nagy Z, Káli Gy, Horváth E, Sánta Zs, El Morr Z (2014) Non-invasive PGAA, PIXE and ToF-ND analyses on Hungarian Bronze Age defensive armour. J Radioanal Nucl Chem 300:787799

7. Oura Y, Saito A, Sueki K, Nakahara H, Tomizawa T, Nishikawa T, Yonezawa C, Matsue H, Sawahata H (1999) Prompt gamma-ray analysis of archaeological bronze. J Radioanal Nucl Chem 239:581-585

8. Molnár G L, Révay Z, Paul R L, Lindstrom R M (1998) Prompt-gamma activation analysis using the k0 approach. J Radioanal Nucl Chem 234:21-26

9. Révay Z, Molnár GL (2003) Standardisation of the prompt gamma activation analysis method. Radiochim Acta 91:361-369

10. Révay Z, Firestone RB, Belgya T, Molnár GL (2004) Prompt Gamma-Ray Spectrum Catalog. In: Molnár GL (ed) Handb. Prompt Gamma Act. Anal. Neutron Beams. Springer US, Boston, MA, pp 173-364

11. Kasztovszky Z, Révay Z, Belgya T, Molnár GL (2000) Nondestructive analysis of metals by PGAA at the Budapest Research Reactor. J Radioanal Nucl Chem 244:379382

12. Kasztovszky Z, Panczyk E, Fedorowicz W, Révay Z (2005) Comparative archaeometrical study of Roman silver coins by prompt gamma activation analysis and SEM-EDX. J Radioanal Nucl Chem 265:193-199

13. Maróti B, Szentmiklósi L, Belgya T (2016) Comparison of low-energy and coaxial HPGe detectors for prompt gamma activation analysis of metallic samples. J Radioanal Nucl Chem. 310:743-749 
Journal of Radioanalytical and Nuclear Chemistry August 2018, Volume 317, Issue 2, pp 1151-1163 DOI: 10.1007/s10967-018-5990-2

14. Developments in prompt gamma-ray neutron activation analysis and cold neutron tomography and their application in non-destructive testing, Stefan Söllradl, PhD dissertation, Universität Bern. https://pdfs.semanticscholar.org/a024/3960ee8b95cfc7e7c5fef574854ed544be44.pdf. Accessed 7 Aug 2017

15. Révay Zs, Kudějová P, Kleszcz K, Söllradl S, Genreith Ch (2015) In-beam activation analysis facility at MLZ, Garching. Nucl Instrum Meth A. 799:114-123

16. Söllradl S, Lührs H, Révay Zs, Kudejova P, Canella L, Türler A (2013) Increasing the dynamic range for the analysis of boron in PGAA. J Radioanal Nucl Chem. 298:20692073

17. Szentmiklósi L, Párkányi D, Sziklai-László I (2016) Upgrade of the Budapest neutron activation analysis laboratory. J Radioanal Nucl Chem. 309:91-99

18. Constantinides I, Gritsch M, Adriaens A, Hutter H, Adams F (2001) Microstructural characterisation of five simulated archaeological copper alloys using light microscopy, scanning electron microscopy, energy dispersive X-ray microanalysis and secondary ion mass spectrometry. Anal Chim Acta 440:189-198

19. Bottaini C, Vilaca R, Schiavon N, Mirao J, Candeias A, Bordalo R, Paternoster G, Montero-Ruiz I (2016) New insights on Late Bronze Age Cu-metallurgy from Coles de Samuel hoard (Central Portugal): A combined multi-analytical approach. J Archaeol Sci Rep. 7:344-357

20. Charalambous A, Kassianidou V, Papasavvas G (2014) A compositional study of Cypriot bronzes dating to the Early Iron Age using portable X-ray fluorescence spectrometry (pXRF). J Archaeol Sci 46:205-216

21. Rehren Th, Boscher L, Pernicka E (2012) Large scale smelting of speiss and arsenical copper at Early Bronze Age Arisman, Iran. J Archaeol Sci 39:1717-1727

22. Ingelbrecht C, Adriaens A, Maier E A. BCR Information Reference Materials, The certification of $\mathrm{As}, \mathrm{Pb}, \mathrm{Sn}$ and $\mathrm{Zn}$ (mass fractions) in Five Copper Alloys, Report EUR 19778/1 EN, 2001.

23. Arana G, Wätjen U, Ingelbrecht C, Robouch P (2003) Bronze analysis by k0-NAA and PIXE. J Radioanal Nucl Chem 257:603-608 
Journal of Radioanalytical and Nuclear Chemistry August 2018, Volume 317, Issue 2, pp 1151-1163 DOI: 10.1007/s10967-018-5990-2

24. Dungworth D (1997) Roman Copper Alloys: Analysis of Artefacts from Northern Britain. J Archaeol Sci 24: 901-910

25. Craddock P T (1978) The Composition of the Copper Alloys used by the Greek, Etruscan and Roman Civilizations. J Archaeol Sci 5: 1-16

26. Lechtman H, Klein S (1999) The Production of Copper-Arsenic Alloys (Arsenic Bronze) by Cosmelting: Modern Experiment, Ancient Practice. J Archaeol Sci 26: 497526

27. Merkl M B (2010) Bell Beaker Metallurgy and the Emergence of Fahlore-copper Use in Central Europe. Interdiscip Archaeol I:19-27.

28. Czajlik Z (2012) A Kárpát-medence fémnyersanyag-forgalma a későbronzkorban és a vaskorban, Tálentum könyvek, ELTE BTK Régészettudományi Intézet, Budapest, ISBN: 9789632842783 (in Hungarian)

29. Szentmiklósi L, Belgya T, Révay Z, Kis Z (2010) Upgrade of the prompt gamma activation analysis and the neutron-induced prompt gamma spectroscopy facilities at the Budapest research reactor. J Radioanal Nucl Chem. 286:501-505

30. Heinz Maier-Leibnitz Zentrum, Révay Z (2015) PGAA: Prompt gamma and in-beam neutron activation analysis facility. J Large-Scale Res Facil 1:1-3.

doi: http://dx.doi.org/10.17815/jlsrf-1-46

31. Fazekas B, Belgya T, Dabolczi L, et al (1996) HYPERMET-PC: Program for Automatic Analysis of Complex Gamma-Ray Spectra. J Trace Microprobe Tech $14: 167-172$.

32. Szentmiklósi L (2018) Fitting special peak shapes of prompt gamma spectra. J Radioanal Nucl Chem 315:663-670 . doi: 10.1007/s10967-017-5589-z

33. Revay Z (2009) Determining Elemental Composition Using PromptGamma Activation Analysis. Anal Chem 81:6851-6859

34. Révay Z (2006) Calculation of uncertainties in prompt gamma activation analysis. Nucl Instrum Methods Phys Res A 564:688-697

35. Szentmiklosi L, Revay Z, Belgya T, et al (2008) Combining prompt gamma activation analysis and off-line counting. J Radioanal Nucl Chem 278:657-660

36. 2015 edition of $k_{0}$ database. 
Journal of Radioanalytical and Nuclear Chemistry August 2018, Volume 317, Issue 2, pp 1151-1163 DOI: 10.1007/s10967-018-5990-2

http://www.kayzero.com/k0naa/k0naaorg/Nuclear_Data_SC/Entries/2016/1/11_New_

k0-data_Library_2015_files/k0_database_2015_12_04.xls Accessed 20 September $\underline{2017}$

37. Kis Z, Szentmiklósi L, Belgya T et al (2015) Neutron based imaging and elementmapping at the Budapest Neutron Centre. Phys Proc 69:40-47

38. Jaćimović R, De Corte F, Kennedy G, Vermaercke P, Revay Z (2014) The 2012 recommended $k_{0}$ database. J Radioanal Nucl Chem 300:589-592

39. Simonits, A., Ostor, J., Kalvin, S. et al. (2003): HyperLab: A new concept in gammaray spectrum analysis J. Radioanal. Nucl. Chem. 257:589-595

40. De Corte, F, Simonits, A (1994): Vade Mecum for k0-Users, Addendum to the KAYZERO/SOLCOI software package. DSM Research, Gellen (NL), R94/11492, 25

41. Chilian C, Kennedy G (2012) Enhancement of thermal neutron self-shielding in materials surrounded by reflectors. J Radioanal Nucl Chem. 293: 179-183

42. Technical specifications - bAxil Software Package. http://www.brightspec.be/brightspec/downloads/bAXIL_Spec_V1.1_Extensive.pdf Accessed 9 October 2017

43. Currie L A (1968) Limits for Qualitative Detection and Quantitative Determination. Anal Chem 40:586-593

44. Révay Z, Belgya T (2004) Principles of the PGAA method. In: Molnár GL (ed) Handb. Prompt Gamma Act. Anal. Neutron Beams. Springer US, Boston, MA, pp 1-30 
Journal of Radioanalytical and Nuclear Chemistry August 2018, Volume 317, Issue 2, pp 1151-1163 DOI: 10.1007/s10967-018$5990-2$

2 Table 4: results of the quaternary alloy, brass, arsenic copper, lead-bronze and tin-bronze samples (BCR-691 A-E) using different

3 PGAA settings and a handheld XRF device in $\mathrm{m} \%$ unit. The certified reference and informative values are marked with bold and italic

4 letters, respectively. < DL implies if the element was below the detection limits under the given measurement conditions. N/A indicates

5 if an element can not be detected due to methodological or nuclear physics reasons.

Quaternary bronze (BCR-A)

\begin{tabular}{|c|c|c|c|c|c|c|c|c|c|c|c|c|c|c|c|c|c|c|}
\hline & $\begin{array}{l}\text { Ref } \\
\text { values }\end{array}$ & \pm & $\begin{array}{c}\text { NAA } \\
{[23]}\end{array}$ & \pm & $\begin{array}{c}\text { PIXE } \\
{[23]}\end{array}$ & \pm & $\begin{array}{c}\text { PGA } \\
\text { A }\end{array}$ & \pm & $\begin{array}{c}\text { attenua } \\
\text { ted } \\
\text { PGAA }\end{array}$ & \pm & $\begin{array}{c}\text { high } \\
\text { resolution } \\
\text { PGAA }\end{array}$ & \pm & $\begin{array}{c}\text { in-beam } \\
\text { NAA }\end{array}$ & \pm & NAA & \pm & XRF & \pm \\
\hline $\mathrm{Cu}$ & matrix & $\mathrm{k}=2$ & & $\mathrm{k}=2$ & & $\mathrm{k}=2$ & 76 & 0.9 & 77 & 0.8 & $* *$ & & $* *$ & & & & & \\
\hline As & 0.194 & 0.10 & 0.190 & 0.011 & 0.165 & 0.069 & 0.21 & 0.02 & N.D. * & & 0.17 & 0.007 & 0.188 & 0.006 & 0.185 & 0.008 & $N / A$ & \\
\hline $\mathbf{P b}$ & 7.9 & 0.7 & N/A & & 8.12 & 1.4 & 8 & 1 & 7 & 0.6 & $N / A$ & & N/A & & N/A & & 8.1 & 0.6 \\
\hline Sn & 7.16 & 0.21 & 6.92 & 0.42 & 6.78 & 1.1 & 7.1 & 0.26 & 7.9 & 0.3 & 8.6 & 0.4 & 8.3 & 0.4 & 6.4 & 0.5 & 7.1 & 0.1 \\
\hline $\mathbf{Z n}$ & 6.02 & 0.22 & 6.22 & 0.35 & 6.06 & 1.0 & 6.8 & 0.3 & 6.0 & 0.3 & 6.6 & 0.3 & 6.3 & 0.4 & 5.7 & 0.2 & 5.7 & 0.2 \\
\hline$S b$ & 0.5 & & 0.514 & 0.029 & 0.44 & 0.07 & N.D. & & N.D.* & 0 & 0.63 & 0.04 & 0.490 & 0.009 & 0.46 & 0.02 & 0.46 & 0.01 \\
\hline$N i$ & 0.1 & & & & & & 0.10 & 0.008 & 0.11 & 7 & $<D L$ & & N.D. * & & $<D L$ & & 0.095 & 0.008 \\
\hline$M n$ & 0.2 & & & & & & 0.280 & 0.009 & 0.17 & 0.1 & 0.21 & 0.01 & 0.205 & 0.007 & N/A & & 0.178 & 0.007 \\
\hline $\mathrm{Fe}$ & 0.2 & & & & & & $<D$. & & $<D L$ & & $<D L$ & & N.D. * & & N/A & & 0.245 & 0.007 \\
\hline$A g$ & no data & & & & & & N/A & & N/A & & 0.013 & 0.001 & N.D. & & 0.011 & 0.002 & $<D L$ & \\
\hline
\end{tabular}

Brass (BCR-B) 
Journal of Radioanalytical and Nuclear Chemistry August 2018, Volume 317, Issue 2, pp 1151-1163 DOI: 10.1007/s10967-0185990-2

\begin{tabular}{|c|c|c|c|c|c|c|c|c|c|c|c|c|c|c|c|c|c|c|}
\hline & $\begin{array}{l}\text { Ref } \\
\text { values }\end{array}$ & \pm & $\begin{array}{l}\text { NAA } \\
\text { [21] }\end{array}$ & \pm & $\begin{array}{c}\text { PIXE } \\
{[21]}\end{array}$ & \pm & $\begin{array}{c}\text { PGA } \\
\text { A }\end{array}$ & \pm & $\begin{array}{c}\text { atte- } \\
\text { nuated } \\
\text { PGAA }\end{array}$ & \pm & $\begin{array}{c}\text { high } \\
\text { resolution } \\
\text { PGAA }\end{array}$ & \pm & $\begin{array}{c}\text { in-beam } \\
\text { NAA }\end{array}$ & \pm & NAA & \pm & XRF & \pm \\
\hline $\mathrm{Cu}$ & matrix & $\begin{array}{c}\mathrm{k}=2 \\
0.01\end{array}$ & & $\mathrm{k}=2$ & & $\mathrm{k}=2$ & 81 & 0.6 & 81 & & $* *$ & & $* *$ & & & & & \\
\hline As & 0.099 & 0 & 0.0989 & 0.0057 & 0.112 & 0.056 & 0.09 & 0.04 & N.D.* & & 0.080 & 0.008 & 0.097 & 0.002 & 0.082 & 0.005 & N.D. & \\
\hline $\mathbf{P b}$ & 0.39 & 0.04 & N.D. & & 0.39 & 0.13 & $<$ DL & & $<\mathrm{DL}$ & & N.D.* & & N.D.* & & N.D.* & & 0.55 & 0.02 \\
\hline Sn & 2.06 & 0.07 & 2.05 & 0.15 & 2.02 & 0.31 & 2.0 & 0.13 & 2.2 & 0.1 & $<\mathrm{DL}$ & & 2.1 & 0.2 & 1.9 & 0.3 & 2.08 & 0.07 \\
\hline $\mathrm{Zn}$ & 14.8 & 0.05 & 15.6 & 0.8 & 14.8 & 2.3 & 15 & 0.6 & 15 & 0.7 & 14.4 & 0.3 & 15.1 & 0.5 & 14.6 & 0.5 & 14.8 & 0.5 \\
\hline$S b$ & -- & & 0.00121 & 0.00012 & & & N.D. & & N.D.* & & $<\mathrm{DL}$ & & N.D. & & 0.0014 & 0.0002 & N.D. & \\
\hline$N i$ & 0.2 & & & & & & 0.27 & 0.015 & 0.24 & 0.01 & $<\mathrm{DL}$ & & N.D.* & & $<\mathrm{DL}$ & & 0.21 & 0.01 \\
\hline$M n$ & 0.4 & & & & & & 0.49 & 0.04 & 0.37 & 0.02 & 0.47 & 0.02 & 0.41 & 0.01 & N.D.* & & 0.32 & 0.06 \\
\hline $\mathrm{Fe}$ & 0.5 & & & & & & 0.57 & 0.05 & 0.48 & 0.05 & $<\mathrm{DL}$ & & N.D.* & & N.D.* & & 0.52 & 0.01 \\
\hline$A g$ & no data & & no data & & $\begin{array}{l}\text { no } \\
\text { data }\end{array}$ & & N.D. & & N.D. & & 0.012 & 0.008 & N.D. & & 0.012 & 0.002 & N.D. & \\
\hline
\end{tabular}

Arsenic-copper (BCR-C)

\begin{tabular}{|c|c|c|c|c|c|c|c|c|c|c|c|c|c|c|c|c|c|c|}
\hline & $\begin{array}{l}\text { Ref } \\
\text { values }\end{array}$ & \pm & $\begin{array}{c}\text { NAA } \\
{[23]}\end{array}$ & \pm & $\begin{array}{c}\text { PIXE } \\
{[23]}\end{array}$ & \pm & $\begin{array}{c}\text { PGA } \\
\text { A }\end{array}$ & \pm & $\begin{array}{c}\text { attenua } \\
\text { ted } \\
\text { PGAA }\end{array}$ & \pm & $\begin{array}{c}\text { high } \\
\text { resolution } \\
\text { PGAA }\end{array}$ & \pm & $\begin{array}{c}\text { in-beam } \\
\text { NAA }\end{array}$ & \pm & NAA & \pm & XRF & \pm \\
\hline $\mathrm{Cu}$ & matrix & $\mathrm{k}=2$ & & $\mathrm{x}=2$ & & $\mathrm{k}=2$ & 95 & & 95 & & $* *$ & & $* *$ & & & & & \\
\hline As & 4.6 & $\begin{array}{l}0.27 \\
0.01\end{array}$ & 4.6 & 0.26 & 6.49 & 1.02 & 5.0 & 0.4 & 4.6 & 0.4 & 4.8 & 0.3 & 4.6 & 0.2 & 4.7 & 0.2 & N.D. & \\
\hline $\mathbf{P b}$ & 0.175 & $\begin{array}{r}4 \\
0.02\end{array}$ & N.D. & & N.D. & & $<\mathrm{DL}$ & & $<\mathrm{DL}$ & & N.D.* & & N.D.* & & N.D.* & & 0.37 & 0.04 \\
\hline Sn & 0.202 & $\begin{array}{r}9 \\
0.00\end{array}$ & 0.205 & 0.035 & 0.24 & 0.06 & 0.39 & 0.05 & $<\mathrm{DL}$ & & $<\mathrm{DL}$ & & $<\mathrm{DL}$ & & $<\mathrm{DL}$ & & 0.22 & 0.03 \\
\hline Zn & 0.055 & 5 & 0.0606 & 0.0075 & 0.058 & 0.034 & $<\mathrm{DL}$ & & $<\mathbf{D L}$ & & $<\mathrm{DL}$ & & $<\mathrm{DL}$ & & 0.054 & 0.014 & N.D. & \\
\hline
\end{tabular}


Journal of Radioanalytical and Nuclear Chemistry August 2018, Volume 317, Issue 2, pp 1151-1163 DOI: 10.1007/s10967-0185990-2

\begin{tabular}{|c|c|c|c|c|c|c|c|c|c|c|c|c|c|c|}
\hline$S b$ & 0.5 & 0.478 & 0.027 & 0.50 & 0.09 & N.D. & N.D. & 0.1 & 0.54 & 0.08 & 0.46 & 0.02 & 0.49 & 0.03 \\
\hline$N i$ & -- & & & & & $<\mathrm{DL}$ & $<\mathrm{DL}$ & N.D.* & N.D.* & & $<\mathrm{DL}$ & & N.D. & \\
\hline$M n$ & 0.2 & & & & & $\mathbf{0 . 1 9 0} \quad 0.005$ & $<\mathrm{DL}$ & $\mathbf{0 . 3 0} \quad 0.015$ & 0.201 & 0.005 & N.D.* & & 0.15 & 0.05 \\
\hline $\mathrm{Fe}$ & 0.2 & & & & & $<\mathrm{DL}$ & $<\mathrm{DL}$ & $<\mathrm{DL}$ & N.D.* & & N.D.* & & 0.19 & 0.02 \\
\hline$A g$ & data & no data & & $\begin{array}{l}\text { no } \\
\text { data }\end{array}$ & & N.D. & N.D. & $<$ DL (200 ppm) & & & 0.013 & 0.001 & N.D. & \\
\hline
\end{tabular}

\begin{tabular}{|c|c|c|c|c|c|c|c|c|c|c|c|c|c|c|c|c|c|c|}
\hline & & \multicolumn{17}{|c|}{ Lead-bronze (BCR-D) } \\
\hline & $\begin{array}{l}\text { Ref } \\
\text { values }\end{array}$ & \pm & $\begin{array}{c}\text { NAA } \\
{[23]}\end{array}$ & \pm & $\begin{array}{c}\text { PIXE } \\
{[23]}\end{array}$ & \pm & $\begin{array}{c}\text { PGA } \\
\text { A }\end{array}$ & \pm & $\begin{array}{l}\text { attenua } \\
\text { ted } \\
\text { PGAA }\end{array}$ & \pm & $\begin{array}{c}\text { high } \\
\text { resolution } \\
\text { PGAA }\end{array}$ & \pm & $\begin{array}{c}\text { in-beam } \\
\text { NAA }\end{array}$ & \pm & NAA & \pm & XRF & \pm \\
\hline $\mathrm{Cu}$ & matrix & $\begin{array}{c}\mathrm{k}=2 \\
0.02\end{array}$ & & $x=2$ & & $\mathrm{k}=2$ & 79 & 1.3 & 82 & & $* *$ & & $* *$ & & & & & \\
\hline As & 0.285 & 2 & 0.289 & 0.016 & 0.271 & 0.094 & 0.34 & 0.03 & N.D.* & & 0.25 & 0.02 & 0.277 & 0.006 & 0.27 & 0.01 & N.D. & \\
\hline $\mathbf{P b}$ & 9.2 & 0.17 & N.D. & & 9.5 & 2.1 & 10 & 1.3 & 7.0 & 0.7 & N.D.* & & N.D.* & & N.D.* & & 10.9 & 0.6 \\
\hline Sn & 10.1 & $\begin{array}{r}0.8 \\
0.02\end{array}$ & 10.3 & 0.6 & 9.79 & 1.53 & 9.9 & 0.35 & 10.1 & 0.3 & 11.0 & 0.5 & $<$ DL & & 9.1 & 0.5 & 9.65 & 0.26 \\
\hline $\mathbf{Z n}$ & 0.148 & 4 & 0.157 & 0.010 & 0.21 & 0.08 & $<\mathrm{DL}$ & & $<\mathrm{DL}$ & & $<\mathrm{DL}$ & & $<\mathrm{DL}$ & & 0.14 & 0.01 & N.D. & \\
\hline$S b$ & 0.3 & & 0.321 & 0.018 & 0.233 & 0.038 & N.D. & & N.D.* & & 0.19 & 0.02 & 0.291 & 0.007 & 0.27 & 0.01 & 0.276 & 0.015 \\
\hline$N i$ & 0.3 & & & & & & 0.32 & 0.02 & 0.34 & 0.02 & N.D.* & & N.D.* & & $<\mathrm{DL}$ & & 0.285 & 0.008 \\
\hline$M n$ & 0.1 & & & & & & $<\mathrm{DL}$ & & 0.22 & 0.02 & 0.16 & 0.01 & 0.104 & 0.003 & N.D.* & & 0.06 & 0.04 \\
\hline $\mathrm{Fe}$ & 0.1 & & & & & & $<\mathrm{DL}$ & & $<\mathrm{DL}$ & & $<\mathrm{DL}$ & & N.D.* & & N.D.* & & 0.061 & 0.003 \\
\hline$A g$ & no data & & no data & & $\begin{array}{l}\text { no } \\
\text { data }\end{array}$ & & N.D. & & N.D. & & 0.018 & 0.002 & N.D. & & 0.011 & 0.001 & N.D. & \\
\hline
\end{tabular}

Tin-bronze (BCR-E) 
Journal of Radioanalytical and Nuclear Chemistry August 2018, Volume 317, Issue 2, pp 1151-1163 DOI: 10.1007/s10967-0185990-2

\begin{tabular}{|c|c|c|c|c|c|c|c|c|c|c|c|c|c|c|c|c|c|c|}
\hline & $\begin{array}{l}\text { Ref } \\
\text { values }\end{array}$ & \pm & $\begin{array}{c}\text { NAA } \\
{[23]}\end{array}$ & \pm & $\begin{array}{c}\text { PIXE } \\
\text { [23] }\end{array}$ & \pm & $\begin{array}{c}\text { PGA } \\
\text { A }\end{array}$ & \pm & $\begin{array}{l}\text { attenua } \\
\text { ted } \\
\text { PGAA }\end{array}$ & \pm & $\begin{array}{c}\text { high } \\
\text { resolution } \\
\text { PGAA }\end{array}$ & \pm & $\begin{array}{c}\text { in-beam } \\
\text { NAA }\end{array}$ & \pm & NAA & \pm & XRF & \pm \\
\hline $\mathrm{Cu}$ & matrix & $\mathrm{k}=2$ & & $=2$ & & $=2$ & 91 & & 92 & & $* *$ & & $* *$ & & & & & \\
\hline As & 0.194 & $\begin{array}{l}0.02 \\
0.01\end{array}$ & 0.196 & 0.011 & 0.24 & 0.05 & 0.17 & 0.02 & N.D.* & & 0.15 & 0.007 & 0.195 & 0.006 & 0.213 & 0.009 & N.D. & \\
\hline $\mathbf{P b}$ & 0.204 & 8 & N.D. & & N.D. & & $<\mathrm{DL}$ & & $<\mathbf{D L}$ & & N.D.* & & N.D.* & & N.D.* & & 0.29 & 0.02 \\
\hline Sn & 7.0 & $\begin{array}{r}0.6 \\
0.02\end{array}$ & 6.90 & 0.43 & 7.32 & 1.18 & 7.8 & 0.3 & 6.7 & 0.2 & 6.3 & 0.3 & 6.4 & 0.4 & 6.7 & 0.5 & 7.30 & 0.08 \\
\hline $\mathbf{Z n}$ & 0.157 & 5 & 0.169 & 0.011 & 0.15 & 0.12 & $<\mathrm{DL}$ & & $<\mathrm{DL}$ & & $<\mathrm{DL}$ & & $<\mathrm{DL}$ & & 0.15 & 0.02 & N.D. & \\
\hline$S b$ & 0.7 & & 0.732 & 0.041 & 0.65 & 0.11 & N.D. & & N.D.* & & 0.60 & 0.09 & 0.71 & 0.01 & 0.62 & 0.02 & 0.68 & 0.05 \\
\hline$N i$ & 0.5 & & & & & & 0.53 & 0.02 & 0.52 & 0.02 & N.D.* & & N.D.* & & 0.4 & 0.1 & 0.47 & 0.01 \\
\hline$M n$ & 0.3 & & & & & & 0.38 & 0.02 & 0.41 & 0.02 & $<\mathrm{DL}$ & & 0.299 & 0.008 & N.D.* & & 0.27 & 0.04 \\
\hline $\begin{array}{l}F e \\
A g\end{array}$ & $\begin{array}{r}0.3 \\
\text { no data }\end{array}$ & & no data & & $\begin{array}{l}\text { no } \\
\text { data }\end{array}$ & & $\begin{array}{l}<\text { DL } \\
\text { N.D. }\end{array}$ & & $\begin{array}{l}<\mathrm{DL} \\
\text { N.D. }\end{array}$ & & $\begin{array}{l}<\mathrm{DL} \\
\quad 0.018\end{array}$ & 0.001 & $\begin{array}{l}\text { N.D.* } \\
\text { N.D. }\end{array}$ & & $\begin{array}{l}\text { N.D.* } \\
\quad 0.013\end{array}$ & 0.001 & $\begin{array}{l}\mathbf{0 . 3 2 7} \\
\text { N.D. }\end{array}$ & 0.014 \\
\hline
\end{tabular}

$6 \quad * *$ from conventional PGAA (relative) 